\title{
Front Matter: Volume 6994
}

, "Front Matter: Volume 6994," Proc. SPIE 6994, Photon Management III, 699401 (12 May 2008); doi: 10.1117/12.797941

SPIE. Event: SPIE Photonics Europe, 2008, Strasbourg, France 


\title{
PROCEEDINGS OF SPIE
}

\section{Photon Management III}

\author{
John T. Sheridan \\ Frank Wyrowski \\ Editors
}

9-10 April 2008

Strasbourg, France

Sponsored by

SPIE Europe

Cosponsored by

Alsace International (France)

Conseil Général du Bas-Rhin (France)

Région Alsace (France)

Communauté Urbaine de Strasbourg (France)

Cooperating Organizations

AFOP_Association Française des Industries de l'Optique et de la Photonique (France)

EOS_European Optical Society (Germany) • EPIC—European Photonics Industry Consortium

(France) - ePIXnet (Belgium) • IOP—Institute of Physics (United Kingdom) • NEMO—Network of

Excellence on Micro-Optics (Belgium) • OLAS (Italy) • The OLLA Project (Germany) • OPERA 2015

(Belgium) • PhOREMOST (Ireland) • Photonics Knowledge Transfer Network (United Kingdom)

Photonics Cluster (United Kingdom) • Photonics4Life (Germany) • Photonics 21 (Germany)

RhenaPhotonics Alsace (France)

Published by

SPIE

Volume 6994

Proceedings of SPIE, 0277-786X, v. 6994 
The papers included in this volume were part of the technical conference cited on the cover and title page. Papers were selected and subject to review by the editors and conference program committee. Some conference presentations may not be available for publication. The papers published in these proceedings reflect the work and thoughts of the authors and are published herein as submitted. The publisher is not responsible for the validity of the information or for any outcomes resulting from reliance thereon.

Please use the following format to cite material from this book:

Author(s), "Title of Paper," in Photon Management III, edited by John T. Sheridan, Frank Wyrowski, Proceedings of SPIE Vol. 6994 (SPIE, Bellingham, WA, 2008) Article CID Number.

ISSN 0277-786X

ISBN 9780819471925

Published by

SPIE

P.O. Box 10, Bellingham, Washington 98227-0010 USA

Telephone +1 3606763290 (Pacific Time) · Fax +1 3606471445

SPIE.org

Copyright (C 2008, Society of Photo-Optical Instrumentation Engineers

Copying of material in this book for internal or personal use, or for the internal or personal use of specific clients, beyond the fair use provisions granted by the U.S. Copyright Law is authorized by SPIE subject to payment of copying fees. The Transactional Reporting Service base fee for this volume is $\$ 18.00$ per article (or portion thereof), which should be paid directly to the Copyright Clearance Center (CCC), 222 Rosewood Drive, Danvers, MA 01923. Payment may also be made electronically through CCC Online at copyright.com. Other copying for republication, resale, advertising or promotion, or any form of systematic or multiple reproduction of any material in this book is prohibited except with permission in writing from the publisher. The CCC fee code is $0277-786 \mathrm{X} / 08 / \$ 18.00$.

Printed in the United States of America.

Publication of record for individual papers is online in the SPIE Digital Library.

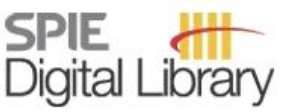

SPIEDigitallibrary.org

Paper Numbering: Proceedings of SPIE follow an e-First publication model, with papers published first online and then in print and on CD-ROM. Papers are published as they are submitted and meet publication criteria. A unique, consistent, permanent citation identifier (CID) number is assigned to each article at the time of the first publication. Utilization of CIDs allows articles to be fully citable as soon they are published online, and connects the same identifier to all online, print, and electronic versions of the publication. SPIE uses a six-digit CID article numbering system in which:

- The first four digits correspond to the SPIE volume number.

- The last two digits indicate publication order within the volume using a Base 36 numbering system employing both numerals and letters. These two-number sets start with 00, 01, 02, 03, 04, 05 , $06,07,08,09,0 A, 0 B \ldots 0 Z$, followed by $10-12,20-2 Z$, etc.

The CID number appears on each page of the manuscript. The complete citation is used on the first page, and an abbreviated version on subsequent pages. Numbers in the index correspond to the last two digits of the six-digit CID number. 


\section{Contents}

vii Conference Committee

\section{SESSION 1 PHOTON MANAGEMENT I}

699402 Analytical and numerical analysis of ABCD systems [6994-01]

J. J. Healy, J. T. Sheridan, Univ. College Dublin (Ireland)

$699403 \quad$ Electro-optic time lens model for femtosecond pulses [6994-02]

F. J. Marinho, Univ. de Trás-os-Montes e Alto Douro (Portugal) and Univ. do Porto (Portugal);

L. M. Bernardo, Univ. do Porto (Portugal)

699405 Reliable simulation of optical bridge system by exchanging optical field data [6994-04] Y. Meuret, Vrije Univ. Brussel (Belgium); N. Lindlein, Friedrich-Alexander Univ. Erlangen-Nuremberg (Germany); I. Sieber, Forschungszentrum Karlsruhe GmbH (Germany); I. Arthundo, C. Debaes, Vrije Univ. Brussel (Belgium); W. Grabowski, Warsaw Univ. (Poland) and Institute of Electronic Materials Technology (Poland); R. Buczynski, Warsaw Univ. (Poland); A. Waddie, Heriot-Watt Univ. (United Kingdom); F. Wyrowski, Friedrich Schiller Univ. of Jena (Germany); H. Thienpont, Vrije Univ. Brussel (Belgium)

699406 Novel hemispheric image formation: concepts and applications [6994-05] S. Thibault, P. Konen, P. Roulet, M. Villegas, ImmerVision (Canada)

699407 Wave-optical simulation of a grating lateral shearing interferometer with a periodic incoherent light source [6994-07]

N. Lindlein, S. Wunderlich, I. Harder, K. Mantel, M. Lano, J. Schwider, Univ. of Erlangen-Nürnberg (Germany)

699408 Approximate analytic analysis of scatter from slanted gratings [6994-08]

D. Sabol, J. T. Sheridan, Univ. College Dublin (Ireland)

699409 Fast photorefractive self focusing in InP:Fe semiconductor at near infrared wavelengths [6994-09]

D. Wolfersberger, C. Dan, N. Khelfaoui, N. Fressengeas, Lab. d'accuel du Master Chimie, (France) and Univ. Paul Verlaine Metz (France); L. Hervé, POMA, Univ. d'Angers (France)

6994 OA Grounded frequency selective surface array as millimeter wave beam splitter [6994-10] S. Islam, J. Stiens, I. Jaeger, R. Vounckx, Vrije Univ. Brussel (Belgium)

\section{SESSION 2 PHOTON MANAGEMENT II}

6994 OB Conical refraction: an experimental introduction [6994-11]

T. K. Kalkandjiev, M. A. Bursukova, Conerefringent Optics SL (Spain) 
6994 OD Time-domain fluorescence mammography using early time-reflected signals: finite element approach [6994-13]

J.-P. L'Huillier, Arts et Métiers ParisTech (France)

6994 OF Depth localization of an inclusion within turbid slab media using time-resolved transillumination contrast functions: numerical study [6994-15]

V. Piron, J.-P. L'Huillier, ENSAM Arts et Métiers ParisTech (France)

SESSION $3 \quad$ PHOTON MANAGEMENT III

6994 OG Distortion management of SBS slow light in a single-mode optical fiber by optimization of broadband SBS gain spectrum [6994-17]

L. Ren, Y. Tomita, Univ. of Electro-Communications (Japan)

$6994 \mathrm{OH} \quad$ Non-invasive WDM channel scrambling for secure high data rate optical transmissions [6994-18]

J. Cornejo, J. L. de Bougrenet de la Tocnaye, TELECOM Bretagne (France)

6994 Ol Diffractive optical element for improving the Z-scan technique sensitivity [6994-20]

R. de Saint Denis, M. Fromager, E. Cagniot, K. Ait-Ameur, ENSICAEN-CEA-UCBN (France)

$69940 \mathrm{~J}$ Influence of the incident angle in the performance of LCoS displays [6994-21]

A. Lizana, N. Martin, Univ. Autònoma de Barcelona (Spain); E. Fernandez, A. Márquez, Univ. de Alicante (Spain); I. Moreno, Univ. Miguel Hernández (Spain); C. Iemmi, Univ. de Buenos Aires (Argentina); J. Campos, M. J. Yzuel, Univ. Autònoma de Barcelona (Spain)

6994 OK Chromatic dispersion compensation of a ferroelectric liquid crystal modulator for optical switching applications [6994-22]

M. M. Sánchez-López, Univ. Miguel Hernández (Spain); P. Garcia-Martínez, Univ. de

València (Spain); I. Moreno, Univ. Miguel Hernández (Spain)

6994 OM Vacuum isostatic micro molding of reflective micro-optical structures into polytetrafluoroethylene materials [6994-24]

T. E. Lizotte, O. Ohar, Hitachi Via Mechanics USA, Inc. (USA)

\section{SESSION 4 PHOTON MANAGEMENT IV}

$699400 \quad$ Examination of the photoinitiation processes in photopolymer materials [6994-27]

S. Liu, M. R. Gleeson, S. O'Duill, J. T. Sheridan, Univ. College Dublin (Ireland)

6994 OP Improvement of photopolymer materials for holographic data storage [6994-28]

M. R. Gleeson, S. Liu, C. E. Close, D. Sabol, J. T. Sheridan, Univ. College Dublin (Ireland)

$69940 Q$ Realization and investigaton of diffractive microrelief on the end face of silver-halide waveguide [6994-29]

V. S. Pavelyev, O. Yu. Moiseev, A. V. Volkov, V. A. Eropolov, S. V. Dmitriev, S. V. Karpeev, Image Processing Systems Institute (Russia) and Samara State Aerospace Univ. (Russia);

V. G. Artyushenko, V. V. Kashin, General Physics Institute (Russia) 
$6994 \mathrm{OR}$ On the thermal stability of volume holograms recorded in nanoparticle-polymer composite films [6994-30]

Y. Tomita, T. Nakamura, A. Tago, Univ. of Electro-Communications (Japan)

6994 OS A compact speckle interferometer for measuring low-amplitude low frequency motion [6994-31]

J. P. Ryle, Univ. College Dublin (Ireland); M. Al-Kalbani, St. James's Hospital (Ireland);

U. Gopinathan, Univ. College Dublin (Ireland) and Univ. Stuttgart (Germany); G. Boyle,

D. Coakley, St. James's Hospital (Ireland); J. T. Sheridan, Univ. College Dublin (Ireland)

\section{POSTER SESSION}

6994 OU Focused image creation approaches for macroscopic objects encoded in digital holograms [6994-06]

C. P. Mc Elhinney, B. M. Hennelly, National Univ. of Ireland, Maynooth (Ireland);

T. J. Naughton, National Univ. of Ireland, Maynooth (Ireland) and Univ. of Oulu (Finland)

6994 OV A polarization-sensitive diffractive optical device for document security [6994-33] I. Aubrecht, Police Presidium CR (Czech Republic); M. Miler, Institute of Photonics and Electronics (Czech Republic)

6994 OW Bandwidth, compact support, apertures and the linear canonical transform in ABCD systems [6994-34]

J. J. Healy, J. T. Sheridan, Univ. College Dublin (Ireland)

6994 OY Polarization simultaneous readout for volume holographic storage in LiNbO 3 [6994-36]

W.-C. Su, National Changhua Univ. of Education (Taiwan); C.-Y. Chen, National Yunlin Univ. of Science and Technology (Taiwan); Y.-W. Liu, National Changhua Univ. of Education (Taiwan); C.-H. Lin, Hwa Hisa Institute of Technology (Taiwan); Y. Ouyang, R.O.C. Military Academy (Taiwan)

699410 Cascaded induced lattices in quadratic nonlinear medium [6994-38]

O. V. Borovkova, V. E. Lobanov, A. P. Sukhorukov, M.V. Lomonosov Moscow State Univ. (Russia); A. K. Sukhorukova, Russian State Geological Prospecting Univ. (Russia)

699412 A comparison of wavelet analysis techniques in digital holograms [6994-40] K. M. Molony, National Univ. of Ireland, Maynooth (Ireland); J. Maycock, National Univ. of Ireland, Maynooth (Ireland) and Bielefeld Univ. (Germany); J. B. McDonald, B. M. Hennelly, National Univ. of Ireland, Maynooth (Ireland); T. J. Naughton, National Univ. of Ireland, Maynooth (Ireland) and Univ. of Oulu (Finland)

Author Index 
Downloaded From: https://www.spiedigitallibrary.org/conference-proceedings-of-spie on 26 Apr 2023

Terms of Use: https://www.spiedigitallibrary.org/terms-of-use 


\title{
Conference Committee
}

\author{
Symposium Chairs
}

Hugo Thienpont, Vrije Universiteit Brussel (Belgium)

Patrick P. Meyrueis, Université Louis Pasteur (France)

Giancarlo C. Righini, Istituto di Fisica Applicata Nello Carrara, CNR (Italy)

\section{Conference Chairs}

John T. Sheridan, National University of Ireland, Dublin (Ireland)

Frank Wyrowski, Friedrich-Schiller-Universität Jena (Germany)

\section{Program Committee}

Pierre Ambs, Université de Haute Alsace (France)

Takeji Arai, Chuo University (Japan)

Luis M. Bernardo, Universidade do Porto (Portugal)

Juan-Manuel Campos, Ecole Superieure d'Electricite (Supelec) (France)

Yeong-Ho Ha, Kyungpook National University (South Korea)

Joachim Hein, Friedrich-Schiller-Universität Jena (Germany)

Zbigniew Jaroszewicz, Instytut Optyki Stosowanej (Poland)

Bahram Javidi, University of Connecticut (USA)

Norbert Lindlein, Friedrich-Alexander-Universität Erlangen-Nürnberg (Germany)

M. G. Moharam, College of Optics \& Photonics, University of Central Florida (USA)

Thomas J. Naughton, National University of Ireland, Maynooth (Ireland)

Cristian Neipp, Universidade de Alicante (Spain)

Levent Onural, Bilkent University (Turkey)

Vladimir S. Pavelyev, Samara State Aerospace University (Russia)

Stefano Pelli, Istituto di Fisica Applicata Nello Carrara (Italy)

Peeter M. Saari, Instytut Fizyki (Estonia)

Hagen Schimmel, LightTrans GmbH (Germany)

Colin J. R. Sheppard, National University of Singapore (Singapore)

Boris Spektor, Technion-Israel Institute of Technology (Israel)

Jani Tervo, JoensuU Yliopisto (Finland)

Jari P. Turunen, JoensuU Yliopisto (Finland) 
Session Chairs

1 Photon Management I

Frank Wyrowski, Friedrich-Schiller-Universität Jena (Germany)

2 Photon Management II

Norbert Lindlein, Friedrich-Alexander-Universität Erlangen-Nürnberg

(Germany)

3 Photon Management III

Youri Meuret, Vrije Universiteit Brussel (Belgium)

4 Photon Management IV

John J. Healy, National University of Ireland, Dublin (Ireland) 